\title{
HUBUNGAN PENGETAHUAN WARNA DENGAN HASIL RIAS WAJAH PESTA PADA SISWA TATA KECANTIKAN KULIT SMK NEGERI 1 BERINGIN
}

\author{
Yuspa Hanum, Ramadhani*)
}

Surel: yuspa.hanum@gmail.com

\begin{abstract}
This study aims to determine the knowledge of colors, the results of party makeup and find out the relationship between the knowledge of colors and the results of student makeup on the skin. The population in the study were 30 people. The results of the average score of color knowledge in students amounted to 34.73 with a tendency level categorized as high with the details of 8 students (26.7\%) having high knowledge, 22 students (73.3\%) having sufficient knowledge. On observing party makeup results obtained an average score of 29.63 with a tendency level categorized high with the details of 14 students (46.7\%) getting high makeup results, 16 students (53.3\%) getting the results of makeup that enough.
\end{abstract}

Keywords: Knowledge of Colors, Results of Party Makeup

\section{PENDAHULUAN}

SMK Negeri 1 Beringin merupakan salah satu lembaga pendidikan yang formal dalam bidang kejuruan yang memiliki tekad menjadi lembaga pendidikan dan latihan tingkat menengah kejuruan yang berorientasi pada semua kegiatannya dalam menghasilkan lulusan yang siap berwirausaha baik di dalam negeri maupun luar negeri, untuk mewujudkan kompetisi dan mengembangkan diri secara profesional serta dapat meneruskan pendidikan kejenjang yang lebih tinggi. SMK Negeri 1 Beringin adalah sekolah yang memiliki 5 jurusan yaitu (1) Teknik Komputer Jaringan (2) Perhotelan (3) Tata Busana (4) rekayasa Perangkat Lunak (5) Tata Kecantikan.

\footnotetext{
*) Dra. Yuspa Hanum, MS. Dosen Jurusan PKK FT UNIMED
} 
Secara Khusus tujuan program keahlian tata rias adalah menyiapkan tenaga yang komponen tingkat menengah dibidang kecantikan yang meliputi rias wajah dan rambut serta perawatan kulit dan kuku (Blog SMK Negeri 1 Beringin, 2013).

Dalam rias wajah pesta, yang perlu diperhatikan adalah pemilihan warna untuk foundation, blush on , eye shadow, dan lipstick. Pemilihan warna foundation (alas bedak) yang salah dapat membuat make up terlihat tidak natural dan menyerupai topeng. Sedangkan Eye shadow atau perona mata menciptakan efek berbeda-beda pada mata, tergantung dari warna sekelilingnya yakni warna mata dan warna kulit. Kulit yang terang, sebaiknya memilih nada yang sedang atau senada lebih gelap daripada warna kulit Kusantanti, (2008)

Berdasarkan hasil wawancara yang penulis lakukan dengan guru mata rias wajah pesta malam hari siswa SMK Negeri 1 Beringin yaitu ibu Novika Rahmadani S.Pd, menyatakan bahwasannya hasil belajar siswa tata kecantikan kulit khususnya pada rias wajah pesta masih tergolong rendah, dimana siswa kurang paham pada pemilihan warna kosmetik. Dalam hal ini pemilihan warna kosmetik menjadi salah satu hal yang harus diketahui dan dipahami oleh siswa sehingga dapat diterapkan dalam melakukan praktik rias wajah pesta malam hari.

Pemilihan dan pengaplikasian warna kosmetik dalam menentukan gelap dan terang yang sesuai dan benar pada proses rias wajah sangat menentukan hasil rias wajah pesta yang dikhendaki terutama pada pemilihan warna foundation, blush on, eye shadow dan warna lipstick serta pemakaian kosmetik lainnya seperti pengaplikasian alis, eye linner dan bulu mata.

Berdasarkan latar belakang masalah yang telah dipaparkan diatas, maka penulis tertarik mengadakan penelitian dengan judul "Hubungan Pengetahuan Warna Dengan Hasil Rias Wajah Pesta Pada Siswa Tata Kecantikan Kulit SMK Negeri 1 Beringin.

Tujuan dari penelitian ini agar dalam pelaksanaan pada sasaran dan jelas arahannya adalah: Untuk mengetahui hubungan pengetahuan warna dengan hasil rias wajah pesta 
Siswa Tata Kecantikan Kulit SMK

Negeri 1 Beringin.

\section{METODE PENELITIAN}

Penelitian ini merupakan dekskriftif korelasional, yaitu suatu metode dalam suatu kelompok manusia, suatu objek yang menggambarkan secara sistematis dan akurat mengenai fakta- fakta, sifat-sifat serta fenomena yang diselidiki. Penelitian ini bertujuan untuk melihat hubungan pengetahuan warna dengan hasil rias wajah pesta.

Menurut Arikunto, (2006). Penelitian korelasional bertujuan untuk menemukan ada tidaknya hubungan serta berarti tidaknya hubungan antara variabel bebas (X) Hubungan Pengetahuan Warna dengan variabel terikat (Y) Hasil Rias Wajah Pesta . Penelitian ini dilakukan kepada 30 siswa di kelas XI Tata Kecantikan Kulit.

1. Populasi dan sampel

a. Populasi

Menurut Sugiyono, (2009) Populasi adalah wilayah generalisasi yang terdiri atas objek atau subjek yang mempunyai kualitas dan karakteristik tertentu yang di tetapkan oleh peneliti untuk di pelajari dan kemudian di tarik kesimpulannya.
Populasi penelitian ini adalah siswa Tata Kecantikan Kulit SMK Negeri1 Beringin dengan jumlah 30 siswa.

b. Sampel

Menurut Sugiyono, (2009) sampel adalah sebagian dari populasi. Mengingat jumlah populasi penelitian berjumlah 30 orang, maka metode pengambilan sampel yang di gunakan adalah sampel total (Total Sampling) yaitu sampel yang di ambil dari seluruh populasi yaitu seluruh siswa kelas XI Tata Kecantikan yang berjumlah 30 orang.

Variabel penelitian adalah suatu sifat atau nilai dari orang atau objek yang mempunyai variasi tertentu yang di tetapkan oleh peneliti untuk di pelajari dan kemudian di tarik kesimpulannya Sugiyono, (2009). Dalam penelitian ini yang menjadi variabel bebas (X) adalah Pengetahuan warna. Sedangkan Variabel terikat (Y) adalah hasil rias wajah pesta.

Definisi operasional bertujuan untuk memperjelas pengertian variabel penelitian maka di uraikan objek penelitian Sugiyono, (2009). Dalam penelitian ini maka di definisikan sebagai berikut :

1. Pengetahuan Warna (X) 
Pengetahuan warna merupakan suatu kemampuan yang dimiliki seseorang dalam memeriksa, menilai, dan memperbaiki paduan warna kosmetik tata rias wajah pada warna kulit yang dimiliki seseorang dengan cara mengaplikasikan kosmetik yang diperlukan pada area wajah seperti penggunaan warna foundation, penentuan warna eye shadow, warna blush on dan warna lipstick yang sesuai dengan warna kulit seseorang serta pengaplikasian alis, eye linner dan pemasangan bulu mata.

2. Hasil Rias wajah pesta (Y) Hasil rias wajah pesta yang sempurna merupakan kemampuan seorang siswa dalam menentukan paduan warna kosmetik gelap dan terang yang sesuai pada warna kulit.

Penelitian ini akan di laksanakan di SMK Negeri 1 Beringin, yang berlokasi di Jl. Pendidikan. Instrumen menurut Arikunto, (2010) alat atau fasilitas yang digunakan oleh peneliti dalam mengumpulkan data. Sebelum instrumen digunakan untuk menjaring data tentang pengetahuan warna, maka instrumen perlu diuji coba terlebih dahulu di SMK Negeri 1 Lubuk Pakam pada siswa X Tata
Kecantikan Kulit, sehingga instrument tersebut benar-benar valid. A. Validitas

Perhitungan validitas butir tes dengan teknik kesejajaran skor butir menggunakan rumus Point Biserial, yaitu :

$\mathrm{rp}_{\mathrm{bis}}=\frac{\left(M_{p}-M_{t}\right)}{S_{t}} \sqrt{\frac{p}{q}}$

Dari hasil perhitungan di atas dan dikonsultasikan dengan tabel harga kritik $\mathrm{r}$ product moment pada taraf signifikansi $5 \%$ dengan $\mathrm{N}=30$, yaitu 0,361 maka dapat diketahui bahwa $r_{\text {hitung }}>r_{\text {tabel }}(0,409>0,361)$, maka butir soal nomor 1 termasuk soal yang Valid.

\section{B. Reliabilitas}

Untuk menentukan reliabilitas tes dilakukandengan menggunakan perhitungan memakai rumus Kudder Rieharsen (KR) 20 yaitu :

$$
\mathrm{r}_{11}=\left(\frac{k}{k-1}\right)\left(\frac{S t^{2}-\sum p q}{S t^{2}}\right)
$$

Diketahui :

$\mathrm{k}=46$ (soal yang valid)

$$
\sum Y=805
$$




$$
\begin{aligned}
\mathrm{St}^{2} & =110,072 \\
& \sum Y^{2}=24903
\end{aligned}
$$

$\sum p q=10,619$

Sehingga didapat harga reliabilitas tes hasil belajar ini sebesar 0,924. Setelah dikonsultasikan dengan indeks korelasi termasuk dalam kategori sangat tinggi.

C. Indek Kesukaran Tes

Indeks kesukaran soal ditentukan dengan menggunakan rumus :

$$
\mathrm{P}=\frac{B}{J}
$$

Dari perhitungan di atas dan dikonsultasikan dengan rentang nilai, maka dapat disimpulkan butir soal nomor 1 tergolong sedang.

D. Daya Pembeda

Untuk menentukan daya beda masing-masing item soal digunakan rumus sebagai berikut :

$$
\mathrm{D}=\frac{\mathrm{B}_{\mathrm{A}}}{\mathrm{J}_{\mathrm{A}}}-\frac{\mathrm{B}_{\mathrm{B}}}{\mathrm{J}_{\mathrm{B}}}
$$

Teknik Analisis Data

Setelah semua data terkumpulkan, maka data tersebut segera ditabulasikan dan diolah sesuai 84 dengan tujuan peneliti dan selanjutnya dianalisis secara statistik. Dalam hal ini digunakan teknik analisis data sebagai berikut :

Mentabulasi Data

Data dari setiap variabel penelitian dipaparkan dengan menggunakan metode statistik deskriptif, yaitu untuk menentukan harga rata-rata $(\mathrm{M})$ dan simpangan baku dihitung dengan menggunakan rumus :

\section{Menghitung Mean}

$$
\mathrm{M}=\frac{\sum X}{n}=\frac{1042}{30}=34,73
$$

2.Menghitung Standart Deviasi (SD)

Dengan rumus

$$
S D^{2}=\frac{n \sum X^{2}-\left(\sum X\right)^{2}}{n(n-1)}
$$

Menentukan banyaknya kelas interval dan panjang interval kelas dengan rumus sebagai berikut: (Aturan Sturges)

Menentukan rentang nilai (range atau R) yaitu: Rentang = skor tertinggi-skor terendah Banyaknya kelas interval $(\mathrm{k})=1+$ $3,3 \log n$

Panjang interval kelas $=\frac{R}{k}$ 
Untuk

mengetahui

kecenderungan data ubahan variabel penelitian, maka dilakukan uji kecenderungan dengan menggunakan rata-rata ideal (Mi) dan simpangan baku ideal (Sdi). Adapun rumus mencari harga rata-rata ideal dan simpangan baku ideal adalah:

Rumus rata-rata ideal (Mi):

$\mathrm{Mi}=\frac{\text { Nilai tertinggi ideal }+ \text { Nilai terendah ideal }}{2}$

Rumus simpangan baku ideal (Sdi):

$\mathrm{Sdi}=\frac{\text { Nilai tertinggi ideal }- \text { Nilai terendah ideal }}{6}$

\section{E. Distribusi Hasil Penelitian}

Penelitian ini dilakukan untuk mengetahui hubungan pengetahuan warna dengan hasil rias wajah pesta pada siswa Tata Kecantikan Kulit SMK Negeri 1 Beringin. Penelitian ini dilakukan kepada 30 siswa di kelas XI Tata Kecantikan Kulit. Pengumpulan data dalam penelitian menggunakan tes Pengetahuan warna yang berjumlah 46 soal yang telah diuji validitas dan lembar observasi pengamatan hasil rias wajah pesta yang dinilai oleh empat orang observer (pengamat).

Berdasarkan pengolahan data pengetahuan warna pada rias wajah pesta siswa Tata Kecantikan Kulit SMK Negeri 1 Beringin mayoritas berada diantara skor rata-rata 34,73 yaitu pada interval 33-34 sebanyak 9 orang $(30,0 \%)$. Sedangkan pengetahuan warna kosmetik rias wajah pesta yang berada di atas skor rata-rata terdapat pada interval 35-36, 37-38 dan 39-40 yaitu sebanyak 15 orang $(50 \%)$. Sedangkan skor siswa yang berada dibawah berada pada interval 29-30 dan 31-32 yaitu sebanyak 6 orang (20\%).

Berdasarkan hasil pengelolahan data hasil rias wajah pesta siswa Tata Kecantikan Kulit SMK Negeri 1 Beringin mayoritas berada diantara skor rata-rata 29,63 yaitu pada interval 28-29 sebanyak 11 orang $(36,7 \%)$. Sedangkan hasil rias wajah pesta yang berada di atas skor ratarata sebanyak 14 orang $(46,7 \%)$ dan hasil rias wajah pesta yang berada di bawah skor rata-rata sebanyak 5 orang $(16,6 \%)$.

\section{Uji Persyaratan Analisis}

1. Uji Normalitas

Syarat normal dipenuhi apabila $X_{h}^{2}<$ $X_{t}^{2}$. Taraf signifikansi dalam penelitian ini ditetapkan 5\% $(\alpha=$ 
0,05) dengan derajat kebebasan $(\mathrm{dk}=\mathrm{n}-1)$, dalam hal ini jumlah kelas adalah 6 didasarkan pada kelas interval kurva normal, sehingga derajat kebebasan $(\mathrm{dk})=5$.

Berdasarkan hasil perhitungan diperoleh $\chi^{2}$ hitung $=4,85$. Jika dibandingkan dengan $\chi^{2}$ tabel pada $\mathrm{db}=5$ pada taraf signifikansi $5 \%$ sebesar 11,07 maka $\chi^{2}$ hitung $<\chi_{\text {tabel }}^{2}$ $(4,85<11,07)$ sehingga dapat disimpulkan bahwa sebaran data pengetahuan warna pada rias wajah pesta berdistribusi normal.

Berdasarkan hasil

perhitungan diperoleh $\chi^{2}{ }_{h}=3,83$. Jika dibandingkan dengan $\chi^{2}$ tabel pada $\mathrm{db}=5$ pada taraf signifikansi $5 \%$ sebesar 11, 07 maka $\chi^{2}$ hitung $<\chi_{\text {tabel }}^{2}$ $(3,83<11,07)$ sehingga dapat disimpulkan bahwa sebaran data hasil rias wajah pesta berdistribusi normal.

\section{Uji Linieritas}

Berdasarkan tabel 13 diatas diperoleh $F_{\text {hitung }}$ sebesar 2,264 dan Ftabel dengan dk (9:19) pada $\alpha=0,05$ sebesar 2,42. Hasil $F_{\text {hitung }}<F_{\text {tabel }}$ atau $2,264<2,42$ sehingga dinyatakan persamaan regresi $\hat{Y}=9,555+0,578$ $\mathrm{X}$ adalah linier.
Sedangkan untuk uji keberartian persamaan regresi diperoleh $F_{\text {regresi }}$ sebesar 16,462. Dengan mengkonsultasikan $F_{\text {hitung }}$ terhadap $\mathrm{F}_{\text {tabel }}$ dengan taraf signifikan $5 \%$ dan derajat kebebasan $(1: 28)=$ 4,20. Dengan demikian $F_{\text {hitung }}>F_{\text {tabel }}$ $(16,462>4,20)$, sehingga dapat disimpulkan bahwa koefisien arah regresi $\mathrm{Y}$ atas $\mathrm{X}$ adalah berarti dan dinyatakan signifikan pada taraf $5 \%$.

\section{F.Pengujian Hipotesis}

Pengujian hipotesis dalam penelitian ini diuji dengan menggunakan analisis korelasi product moment yaitu untuk melihat hubungan antara variabel pengetahuan warna $(\mathrm{X})$ dengan hasil rias wajah pesta $(Y)$ pada Siswa Tata Kecantikan Kulit SMK Negeri 1 Beringin.

$$
\text { Berdasarkan }
$$

hasil perhitungan korelasi product moment diperoleh nilai $\mathrm{r}_{\mathrm{xy}}$ adalah sebesar 0,608 yang berarti terdapat hubungan yang cukup berarti antara pengetahuan warna dengan hasil rias wajah pesta siswa Tata Kecantikan Kulit SMK Negeri 1 Beringin. Dari hasil perhitungan uji-t (uji keberartian) diperoleh harga $t_{\text {hitung }}$ p-ISSN : 1693 - 1157, e-ISSN : 2527 - 9041 
sebesar 4,057 sedangkan harga $t_{\text {tabel }}$ dengan derajat kebebasan $(\mathrm{dk}=30-2=$ 28) pada taraf signifikan $5 \%$ adalah 1,70. Berdasarkan hasil pengujian hipotesis diperoleh harga $t_{\text {hitung }}>t_{\text {tabel }}$ $(4,057>1,70)$ sehingga hipotesis yang menyatakan bahwa terdapat hubungan yang signifikan antara pengetahuan warna dengan hasil rias wajah pesta siswa Tata Kecantikan Kulit SMK Negeri 1 Beringin dapat diterima atau teruji kebenarannya. Hal ini berarti, jika pengetahuan siswa baik tentang warna, maka hasil rias wajah pesta yang dilakukan siswa akan semakin baik.

\section{G.Pembahasan Hasil Penelitian}

Berdasarkan hasil penelitian yang telah dilakukan, diperoleh data Pengetahuan warna pada rias wajah pesta siswa Tata Kecantikan Kulit SMK Negeri 1 Beringin dengan skor rata-rata sebesar 34,73 dengan skor tertinggi 34 dan skor terendah 23. Dari hasil tingkat kecenderungan didapatkan bahwa ada 8 siswa (26,7\%) memiliki pengetahuan yang tinggi, 22 siswa $(73,3 \%)$ memiliki pengetahuan yang cukup. Berdasarkan hasil analisis data penelitian tingkat kecenderungan pengetahuan warna pada siswa Tata
Kecantikan SMK Negeri 1 beringin hanya berada pada tingkat kecenderungan tinggi dan cukup. Tidak ada siswa yang memperoleh tingkat kecenderungan yang kurang maupun rendah. Maka secara umum dapat disimpulkan bahwa pengetahuan warna pada siswa Tata Kecantikan Kulit SMK Negeri 1 Beringin cenderung Tinggi. Hasil tersebut menunjukkan bahwa pengetahuan siswa tentang warna pada rias wajah pesta secara keseluruhan masih tergolong tinggi. Akan tetapi masih banyak siswa yang memiliki pengetahuan dengan skor dibawah rata-rata. Hal ini terjadi karena belum sepenuhnya mengetahui dan memahami tentang warna pada rias wajah pesta dengan benar. Pengetahuan siswa yang masih kurang, disebabkan masih kurangnya pemahaman siswa mengenai warna pada rias wajah, maka dari itu diharapkan guru dapat memberikan pemahaman dengan meningkatkan motivasi siswa dan keingintahuan siswa tentang bagaimana menentukan warna pada rias wajah pesta dengan baik dan benar. Pengetahuan warna pada rias wajah pesta merupakan hal yang sangat penting dalam 
melakukan riasan wajah pesta, karena tanpa penentuan warna yang baik maka tidak akan terwujud hasil rias wajah pesta yang sempurna, maka dari itu jelaslah bahwa pengetahuan warna pada rias wajah memegang peranan penting di dalam melakukan rias wajah pesta. Pemilihan warna yang baik akan menentukan hasil riasan wajah yang baik sesuai dengan warna kulit wajah seseorang dan kesempatan. Hal ini sesuai dengan pendapat Kusumawardhani (2014) bahwa warna dalam tata rias mampu menciptakan dimensi pada wajah seseorang, dimana warna dalam kosmetik dapat menutupi kekurangan pada bagian wajah dan menonjolkan keindahan pada wajah seseorang. Dengan permainan warna gelap dan terang dapat membuat kesan wajah lebih dramatis dan harmonis.

Berdasarkan penelitian hasil rias wajah pesta siswa Tata Kecantikan Kulit SMK Negeri 1 Beringin diperoleh skor rata-rata sebesar 29,63 dengan skor tertinggi 35 dan skor terendah 24. Dari hasil tingkat kecenderungan hasil rias wajah pesta dari 30 orang sampel penelitian didapatkan 14 siswa $(46,7 \%)$ mendapatkan hasil rias wajah yang tinggi, 16 siswa $(53,3 \%)$ mendapatkan hasil rias wajah yang cukup. Maka secara umum dapat disimpulkan bahwa hasil rias wajah pesta pada siswa Tata Kecantikan Kulit SMK Negeri 1 Beringin cenderung Tinggi. Hal ini berarti, hasil rias wajah pesta yang dilakukan siswa sudah tergolong baik, akan tetapi perlu dilakukan peningkatan lebih lanjut.

Berdasarkan perhitungan analisis korelasi sebesar 0,608 menunjukkan hubungan yang cukup berarti antara pengetahuan warna dengan hasil rias wajah pesta siswa Tata Kecantikan Kulit SMK Negeri 1 Beringin. Sedangkan hasil perhitungan uji-t (uji keberartian) diperoleh harga $\mathrm{t}_{\text {hitung }}$ sebesar 4,057 sedangkan harga $t_{\text {tabel }}$ dengan derajat kebebasan $(\mathrm{dk}=30-2=28)$ pada taraf signifikan $5 \%$ adalah 1,70 . Berdasarkan hasil pengujian hipotesis diperoleh harga $t_{\text {hitung }}>t_{\text {tabel }}(4,057>$ 1,70) sehingga hipotesis yang menyatakan bahwa terdapat hubungan yang signifikan antara pengetahuan warna dengan hasil rias wajah pesta siswa Tata Kecantikan Kulit SMK Negeri 1 Beringin dapat diterima atau teruji kebenaranya. Hal 
ini berarti, Hal ini berarti, jika pengetahuan siswa baik tentang warna kosmetik rias wajah pesta, maka hasil rias wajah pesta yang dilakukan siswa akan semakin baik.. Pengetahuan siswa yang kurang tentang warna berpengaruh pada hasil rias wajah pesta yang dilakukan siswa. Maka dari itu siswa harus memiliki pengetahuan warna pada rias wajah pesta berhubungan dengan hasil rias wajah pesta yang dilakukan siswa.

\section{DAFTAR PUSTAKA}

Andyanto dan Ayu Isni Karim.

(2010). The Make Over Rahasia

Rias Wajah Sempurna. Jakarta :

Gramedia Pustaka Utama.

Arikunto,Suharsimi. (2006).

Prosedur Penelitian Suatu

Pendekatan Praktek. Jakarta: Rineka cipta.

Arikunto, Suharsimi. (2009). Dasar Dasar Evaluasi Pendidikan. Jakarta: Bumi Aksara.

Aprilia, Ade. (2010). Every day make-up. Jakarta: PT. Gramedia pustaka utama.

Astati, Sutriari. (1996). Rias Wajah Sehari-hari. Jakarta : Departemen Pendidikan dan Kebudayaan, Direktorat Jendral Pendidikan Dasar dan Menengah Direktorat Pendidikan Menengah Kejuruan.
Blog SMK NEGERI 1 Beringin. Diakses pada 20 April 2016 dari,(http://www.smk1beringin .sch.id/profil_visi_misi.html).

Han, Chenny. (2010). Make Up Alis Sesuai Aura \& Feng Shui. Jakarta : Gramedia Pustaka Utama.

Departemen Pendidikan Nasional. (2008). Kamus Besar Bahasa Indonesia Cetakan Ketiga. Jakarta : Balai Pustaka.

Darmaprawira, Sulasmi . (2002).

Warna, Teori dan Kreativitas Penggunaannya . Bandung : Penerbit ITB. 